\title{
KEHADIRAN GENDING MUGI RAHAYU \\ DALAM KONTEKS SOSIAL
}

\author{
Niken Setyani, Rusdiyantoro* \\ Program Studi Seni Karawitan Fakultas Seni Karawitan \\ Institut Seni Karawitan (ISI) Surakarta \\ Email: deejansitororus@gmail.com
}

\begin{abstract}
Abstrak
Permasalahan yang ingin diurai dalam penelitian ini adalah terkait perkembangan fungsi Mugi Rahayu dimasyarakat. Haltersebutatas dasar popularitas gending, kehadiran, dan perkembangan garapnya yang beragam dalam memenuhi beberapa fungsi dan keperluan di dalam masyarakat Jawa Tengah khususnya daerah Surakarta dan sekitarnya. Penelitian ini merupakan penelitian kualitatif yang menggunakan metode deskriptif analisis, yaitu memberikan penjelasan tentang keragaman gending Mugi Rahayu dalam berbagai fungsi dengan menggunakan pendekatan pemikiran Supanggah mengenai teori garap. Hasil analisis yang telah dilakukan, dapat diketahui bahwa ragam garap yang terjadi pada gending Mugi Rahayu terlahir karena memenuhi fungsi yang ada dalam masyarakat Jawa dan menjadikan gending Mugi Rahayu tetap eksis dan sering dipilih sebagai pendukung sajian sosial maupun layanan seni.
\end{abstract}

Kata Kunci: Ragam, Mugi Rahayu, Fungsi, Garap.

\begin{abstract}
The problem to be analyzed in this study is related to the development of Mugi Rahayu's function in society. This is based on the popularity of the gending, the presence and development of its various works in fulfilling several functions and needs in Central Java society, especially in Surakarta area and its surroundings. This research is a qualitative research that uses a descriptive analysis method, which provides an explanation of the diversity of Mugi Rahayu's repertoire in various functions using Supanggah's approach to work on the theory of the works. The results of the analysis that have been carried out, it can be seen that the variety of work that occurs in Mugi Rahayu's music was born because it fulfills functions that exist in Javanese society and makes Mugi Rahayu's music still exist and is often chosen as a supporter of social offerings and art services.
\end{abstract}

Keywords: varieties, Mugi Rahayu, functions, Garap

* Penulis Korespondensi. Program Studi Seni Karawitan Fakultas Seni Pertunjukan Institut Seni Indonesia (ISI) Surakarta. Email: deejansitororus@gmail.com 


\section{Pengantar}

Penelitian ini terfokus pada salah satu gending alit ${ }^{1}$ dengan bentuk ladrang ${ }^{2}$ yaitu gending Mugi Rahayu laras slendro pathet manyura (Hastanto 2009). Gending Mugi Rahayu, sejak kemunculannya sampai saat ini masih tetap eksis dan populer di kalangan para pengrawit dan masyarakat Jawa. Kenyataan tersebut dapat dilihat dari seringnya gending Mugi Rahayu dimainkan dalam berbagai fungsi dan kegunaan yaitu klenèngan ${ }^{3}$, karawitan tari, karawitan pakeliran (wayang), karawitan pahargyan, panembrama ${ }^{4}$, dan tayub (Widyastutieningrum 2007) ${ }^{5}$. Fungsi tersebut merupakan perkembangan gending Mugi Rahayu yang pada awalnya diciptakan oleh Wiryodiningrat sebagai pernyataan doa yang disajikan secara mandiri terlepas dari fungsi dan guna.

Perkembangaan fungsi dan guna ini mengakibatkan gending Mugi Rahayu selalu tampil dengan wajah yang berbeda sesuai dengan keperluan yang menyertainya. Keperluan yang berbeda menyebabkan perlakuan yang berbeda pula pada gending Mugi Rahayu terutama dalam hal garap. Perubahan garap disesuaikan dengan keperluan yang menyertainya. Misalnya untuk keperluan tari, perubahan nampak pada garap ricikan ${ }^{6}$ kendhang dan panembrama pada ricikan vokal.

Perbedaan penyajian (garap) biasa terjadi di antara pengrawit yang satu dengan yang lainnya. Adanya perbedaan garap antara pengrawit yang menyebabkan terjadinya perbedaan garap pada suatu kelompok atau grup karawitan di masingmasing daerah dan juga menimbulkan ragam garap pada gending. Salah satu contohnya adalah garap gending Mugi Rahayu yang dimainkan oleh salah satu kelompok karawitan di Ngawi yang memiliki garap vokal yang berbeda dari biasanya, menurut hemat penulis adalah selain karena kebutuhan penyajian yang berbeda juga memiliki indikasi terjadinya proses kreatif para pengrawitnya. Fenomena di atas tersebut menarik dilakukan penelitian lebih lanjut. Atas dasar fenomena-fenomena tersebut pula penelitian ini berupaya untuk menjawab persoalan perkembangan fungsi dan ragam garap gending Mugi Rahayu terkait dengan fungsi sosialnya. Pembahasan masalah menggunakan teori garapnya Rahayu Supanggah.

Garap merupakan istilah yang tidak asing lagi bagi dunia kesenian karawitan Jawa. Garap merupakan salah satu unsur paling penting yang nantinya akan memberikan warna, kualitas, karakter, bahkan sosok gending. Garap yang disajikan oleh instrumen maupun vokal inilah yang akan menghasilkan dan atau membentuk gending. Sebagaimana yang diungkapkan oleh Rahayu Supanggah mengenai garap sebagai berikut:

"Garap merupakan rangkaian kerja kreatif dari (seseorang atau kelompok) pengrawit dalam menyajikan sebuah gending atau komposisi karawitan untuk dapat menghasilkan wujud (bunyi), dengan kualitas atau hasil tertentu sesuai dengan maksud, keperluan atau tujuan dari suatu kekaryaan atau penyajian karawitan dilakukan (Supanggah 2007, 3).

Hasil kerja kreatif tersebut kemudian memunculkan keragaman garap yang merupakan pencerminan dari prinsip fleksibel yang dimiliki oleh gending (Sutton 1986). Hal ini bisa disebabkan oleh beberapa hal. Kemungkinan kreativitas pengrawit dalam menyikapi kondisi karawitan yang berkembang. Hal ini jelas menerangkan bahwa garap merupakan hasil kerja dari seseorang atau kelompok. Oleh karenanya, banyak hal yang bisa menentukan munculnya sebuah garap.

Keragaman garap pada gending Mugi Rahayu diduga sangat dipengaruhi oleh tindakan kreativitas senimannya. Unsur garap lain yang turut serta mempengaruhi garap musikal karawitan adalah fungsi dan guna gending untuk 
suatu kepentingan serta pengaruh garap lain. Perpaduan unsur-unsur tersebut menghasilkan gending Mugi Rahayu yang berkembang dalam keberagaman. Keberagaman tersebut merupakan sebuah akibat dari proses perjalanan panjang sebuah garap. Kemudian bersaing dalam menghadapi seleksi alam. Untuk mempertahankan keberlangsungan sebuah gending bergantung pada peran seniman untuk selalu berkreasi menghadapi perkembangan dan tuntutan jaman. Keberadaan gending Mugi Rahayu mengalami proses pewarisan tradisi yang panjang yang berdampak pada perkembangan dan perubahan garap gending. Secara tekstual, gending Mugi Rahayu mengalami perkembangan garap yaitu terjadinya perubahan garap sesuai dengan fungsi utamanya dalam klenèngan dan alih laras. Gending Mugi Rahayu berkembang memenuhi berbagai fungsi dan guna di dalam masyarakat. Sebagai hasil warisan tradisi, gending Mugi Rahayu bertahan menjadi bagian gending yang mendapatkan tempat di hati masyarakat. Keragaman garap disesuaikan dengan fungsi atau guna suatu gending. Hingga dewasa ini gending Mugi Rahayu telah banyak mendukung berbagai kepentingan baik dalam fungsi layanan seni maupun fungsi sosial. Seperti ditegaskan oleh Rahayu Supanggah bahwa fungsi yang sangat besar perannya dalam menentukan garap karawitan dibedakan menjadi tiga kelompok yaitu otoritas, fungsi sosial, dan fungsi layanan seni (Supanggah 2007, 249).

\section{Pembahasan}

Gending Mugi Rahayu merupakan iyasan $^{7}$ seorang bangsawan bernama Kanjeng Raden Mas Tumenggung Harya Wiryadiningrat (KRMTH Wiryadiningrat). Beliau merupakan seorang ahli karawitan yang banyak memprakarsai penciptaan gending-gending, antara lain; Duta Hiswara, Ladrang Tirta Kencana, Tanjung Karang, Ladrang Lambangsari Sukawiryo, Muda-Tama, Ladrang Westminster, Ladrang
Pakumpulan, Bargawastra, Ladrang Baitan, Ladrang Siyem, Sri Widada, dan Ladrang Mugi Rahayu(Pradja Pangrawit 1990) (Suhartinah 1981, 58). Gending-gending ciptaan KRMTH Wiryadiningrat memiliki keistimewaan yaitu gending yang disesuaikan dengan keadaan jaman dan memiliki latar belakang penciptaan termasuk pula Ladrang Mugi Rahayu yang diciptakan ketika beliau sedang sakit. Menurut Sudiyono pada awalnya Ladrang Mugi Rahayu bernama Muji Rahayu, tetapi ketika digunakan sebagai koor perkumpulan "PAKASA" singkatan dari Pakumpulan Kawula Surakarta cakepan-nya diganti Mugi Rahayu. Kerangka ini selesai dibuat tepatnya pada malam Selasa Kliwon tanggal 13 malam 14 Mei 1940 bersamaan ketika negeri Belanda diduduki tentara NAZI (Nationalsozialismus) Jerman. Bakunya gending ini terinspirasi dari ladrang Grompol yang diturunkan dua nada atau berjarak salah gumun yang semula gong 5 menjadi gong 2, kemudian diberi senggakan dan gerongan (Martopangrawit 1975, 65). Pada waktu itu Wiryodiningrat sedang sakit influenza ditunggui oleh abdi dalem niyaga Wiryadiningratan (Suhartinah 1981, 60).

Epistimologi gending Mugi Rahayu berasal dari dua kata, yaitu Mugi dan Rahayu ditengarai menggunakan bahasa Jawa baru. Menurut kamus Basa Jawa kata mugi memiliki arti semoga (Widada et al. $2006,524)$. Kata rahayu memiliki arti slamet, begja, luput ing kacilakan utawa kasangsaran (Widada et al. 2006, 652). Sedangkan nama awal gending Mugi Rahayu yaitu Muji Rahayu memiliki arti tersendiri yaitu muji yang berarti sembahyang; ndonga atau berdoa (Poerwadarminta 1939)(Widada et al. 2006, 525). Persamaan antara kata mugi dan muji adalah mendoakan. Sedangkan perbedaannya terletak pada subyek yang melakukan, jika mugi merupakan harapan atau doa dari orang kepada orang lain supaya selamat. Kata muji merupakan doa yang dilakukan langsung kepada Tuhan supaya diberikan selamat kepada diri 
sendiri atau pun orang yang didoakan terkesan lebih intim.

Membahas mengenai struktur gending dalam artian bentuk, menurut Waridi apa yang dimaksud dengan struktur gending mengandung pengertian susunanatau bangunanmusikal (komposisi musikal) yang di dalamnya terdapat unsurunsur atau bagian pembentuk gending. Untuk melihat bagian-bagian dari gending ditandai dengan titik- titik penting yang biasanya dicirikan oleh peletakan instrumen struktural, seperti kethuk, kenong, kempul, dan gong (Waridi 2006, 167-68). Sedangkan bentuk gending merupakan format dan ukuran panjangpendeknya "kalimat lagu" (susunan nada-nada yang merupakan komponen gending itu (Hastanto 2009, 50).

Mugi Rahayu dalam penyajian menggunakan seperangkat gamelan dalam karawitan Jawa khususnya gaya Surakarta merupakan suatu ansambel atau seperangkat instrumen atau ricikan berlaras slendro dan/atau pelog yang digunakan untuk menyajikan gending karawitan Jawa atau dapat disebut gamelan Ageng (Warsapradangga, n.d.).

\section{Mugi Rahayu dalam Konteks Sosial}

Kembali pada diskusi mengenai Mugi Rahayu dalam konteks sosialnya di mana penyajian suatu gending ketika karawitan digunakan untuk melayani berbagai kepentingan kemasyarakatan. Adapun kepentingan yang dimaksud adalah mulai dari yang sifatnya ritual religius, upacara kenegaraan, kemasyarakatan, keluarga maupun perorangan. Dari pengertian tersebut maka fungsi gending Mugi Rahayu dalam kontek sosial dibagi menjadi dua yaitu pahargyan penganten dan panembrama.

\section{a. Pahargyan Pengantèn}

Karawitan selalu digunakan dalam berbagai kegiatan ritual oleh masyarakat di Jawa (Sumarsam 2003), misalnya sebagai bagian dari upacara ritual siklus hidup (pitonan, kelahiran bayi, khitanan, pernikahan, bahkan kematian). Mugi Rahayu sering hadir dalam upacara pernikahan masyarakat Jawa khususnya daerah Surakarta. Gending Mugi Rahayu sering hadir terutama pada acara utama yaitu temu saat prosesi sungkeman. Prosesi sungkeman merupakan tahapan yang penting dalam upacara pernikahan karena sepasang pengantin harus memohon doa restu kepada kedua orang tua supaya kehidupan rumah tangganya sejahtera. Oleh karena itu dipilih gending yang dianggap memiliki berkah yang dilihat dari nama gending yaitu gending Mugi Rahayu. Gending Mugi Rahayu dipilih berdasarkan nama yang memiliki arti mendoakan. Selain nama, di dalam sajian vokal gending Mugi Rahayu terdapat senggakan gawan gending "mugi rahayuo - ayem tentrem, mugi rahayuo - sayuk rukun" yang memiliki arti mendoakan supaya kehidupan sepasang pengantin sejahtera, tentram, dan rukun. Sehingga gending ini pas atau sesuai dengan adegan tersebut. Karena seringnya gending Mugi Rahayu muncul dalam upacara pernikahan, gending ini sering disebut atau dikategorikan sebagai gending pahargyan. Para seniman bahkan secara spontan -untuk daerah yang masih menggunakan pedoman tradisi- menabuh atau memainkan gending ini ketika prosesi sungkeman akan berlangsung. Citra gending ini telah melekat kuat pada upacara mantu, sehingga tidak heran jika para pengrawit sering menggarap gending Mugi Rahayu untuk mendukung jalannya upacara pahargyan.

\section{b. Panembrama}

Panembrama berasal dari kata sembrama yang berarti pnghormatan atau ucapan selamat datang (mbagekake). Panembrama dilakukan dengan memilih gending tertentu dan dibuat cakepan khusus yang disesuaikan dengan peristiwa disajikannya gending (Supanggah 2007, 
252). Ladrang Mugi Rahayu dipilih menjadi bagian dari upacara kenegaraan sebagai gending panembrama pada tahun 1942. Ladrang Mugi Rahayu disajikan untuk mendoakan keselamatan ratu Belanda bernama Ratu Wilhelmina. Nama peristiwa tersebut adalah Panembrama Sociated Mangkunegaran. Informasi tentang penggunaan gending Mugi Rahayu sebagai panembrama atau persembahan tersebut oleh Sudiono dalam "Biografi Tokoh". Martopengrawit menyampaikan informasi yang berbeda dengan Sudiono. Gending Mugi Rahayu panembrama digubah sebagai bentuk do'a atau harapan "Kawula Surakarta" agar Ratu Wilhelminah atau kerajaan Belanda dibebaskan dari penaklukan oleh tentara NAZI Jerman pada tahun 1942. Kedua fungsi yang menggunakan gending Mugi Rahayu sebagai bagian upacara bersifat menghormati suatu peristiwa. Maka gending ini layak digolongkan dalam gending pakurmatan (Subuh 2016).

\section{Fungsi Hubungan atau Layanan Seni}

Fungsi hubungan atau layanan seni adalah peran karawitan dalam mendukung dan/ atau melayani kebutuhan presentasi (bidang atau cabang) kesenian lain seperti tari, teater, wayang, dan sebagainya, baik dalam konteks upacara maupun konteks pertunjukan murni. Karawitan memiliki ribuan repertoar gending yang bersifat fleksibel, artinya dapat digunakan untuk semua keperluan penyajian karawitan, baik untuk klenengan, upacara, dan mendukung presentasi (cabang) kesenian lainnya. Ladrang Mugi Rahayu merupakan salah satu repertoar gending yang sering dijadikan untuk mendukung presentasi cabang lain yaitu:

\section{a. Klenèngan}

Garap klenèngan yaitu cara menyajikan gending dengan memilih vokabuler garap yang berupa teknik, pola, cengkok, wiletan, dan sekaran, yang digarap sepenuhnya oleh pengrawit tanpa dikaitkan dengan kepentingan dan/ atau konteks tertentu di luar kebutuhan penyajian karawitan. Garap klenèngan biasa disajikan secara mandiri dengan tujuan dinikmati dan dihayati oleh penikmat seni. Salah satu repertoar gending yang biasa disajikan secara mandiri adalah gending Mugi Rahayu. Penyajian dilakukan oleh kelompok-kelompok karawitan yang sedang berlatih atau hanya ingin menikmati gending ini saja. Di lingkungan akademis, gending Mugi Rahayu dijadikan sebagai bahan ajar mata perkuliahan tabuh bersama di Institut Seni Surakarta.Penyajian gending Mugi Rahayu dalam klenèngan dipengaruhi oleh aturan-aturan yang terikat oleh pembagian waktu, dalam tradisi Jawa disebut pathet. Dalam konteks ini penyajian gending Mugi Rahayu dalam klenèngan disajikan dalam wilayah pathet manyura. Hal ini terkait dengan acara yang disertainya yaitu sungkeman yang membutuhkan suasana agung dan tidak prenès. Sedangkan dalam sajian klenèngan secara mandiri, gending Mugi Rahayu dapat digarap sesuai dengan keinginan pengrawit. Misalnya gending Mugi Rahayu digarap menggunakan kendangan pola wiled oleh kelompok karawitan Muryoraras pimpinan Suraji. Bahkan ladrang Mugi Rahayu digarap dengan cara dialihlaraskan menjadi laras pelog pathet barang menjadi Rang Ayu. Hal ini terkait dengan kreativitas seniman dalam mengotak-atik garap suatu gending dan menunjukkan bahwa gending merupakan ladang garap yang dapat digarap sedemikian rupa. Pathet mampu mempengaruhi suasana, faktor lain adalah pemilihan gending yang sesuai berdasarkan keperluan.

\section{b. Tari}

Tari merupakan salah satu cabang seni yang didominasi oleh gerakan sebagai hasil karyanya. Gerakan-gerakan tersebut mengandung makna dan merupakan simbol-simbol tertentu yang terangkai menjadi suatu alur dan/atau tema cerita 
dalam satu sajian tari, misalnya beksan Driasmara yang melambangkan seorang laki-laki dan seorang wanita yang sedang jatuh cinta. Untuk mendukung dan menguatkan gerak tari, suasana serta pesan di dalam karya tari, dibutuhkan gending sebagai pendukung musikal yang dimainkan oleh seperangkat gamelan. Gending yang digunakan untuk keperluan tari disebut juga dengan gending beksan. Menurut Supanggah fungsi gending beksan adalah sebagai berikut:

Gending beksan berfungsi untuk mendukungkeberhasilanpenampilan tari, yang utama adalah bagaimana gending dapat menghidupkan tari, nguripké jogèd, bukan semata-mata mengiringi tari. Nguripké jogèd berarti memberi ruh dan karakter pada jogèd, baik melalui tokoh tertentu maupun alur tari; alur ceritera kalau ada (Supanggah 2007, 263) .

Jika gending dapat disajikan secara mandiri, lain halnya dengan seni tari yang selalu didampingi dengan karawitan. Peran gending sangat penting dalam cabang seni yang satu ini, khususnya seni tari gaya Suarakarta. Seperti yang diungkapkan oleh Trusta bahwa seni tari merupakan salah satu bentuk seni yang tidak dapat berdiri sendiri, di dalam penyajiannya sangat tergantung pada karawitan, karena tempo, ritme, suasana, dalam pertunjukan tari sangat ditentukan oleh karawitan (Trustho 2005, 38). Karena sifatnya yang tidak dapat berdiri sendiri maka garap irama dan/atau laya (tempo) serta volume sajian sangat penting. Irama dan laya sangat erat dengan pilihan cengkok dan wiled, sedangkan volume sangat efektif dalam memberikan penekanan terhadap gerak tertentu dan/atau terhadap emosional penari (Supanggah 2007, 263). Mayoritas tari menggunakan repertoar gending yang sudah ada yaitu repertoar gending klenèngan. Bahkan banyak karya tari yang menggunakan nama gending sebagai judul karya tari. Misalnya pada jenis-jenis tari Bedhaya, Srimpi, Gambyong, dan Golèk yaitu Bedhaya Kaduk Manis, Srimpi Anglir Mendhung, Gambyong Pangkur, sekar Pudyastuti (Megawati 2018) dan obyek penelitian ini yaitu Mugi Rahayu sebagai gending beksan yang disebut Beksan GolekMugi Rahayu. Hal inimengindikasikan bahwa gending diciptakan terlebih dahulu daripada gerakan tarinya. Garap gending Mugi Rahayu untuk kepentingan tari tidak jauh berbeda dengan garap klenèngan. Pada garap karawitan tari, kendang merupakan ricikan yang sangat penting dalam menentukan irama dan/atau laya serta gerak penari. Antara kendang dan gerakan tari sering terikat sehingga pola kendangan atau sekaran yang dimainkan sering diberi nama yang mewakili gerakan tari pula. Kendang digarap lebih menonjol dengan volume yang lebih keras dengan laya lebih cepat (seseg) daripada untuk keperluan klenèngan. Gending Mugi Rahayu, garap kendangnya disesuaikan dengan gerak tarinya.

\section{c. Тayub}

Tayub adalah bentuk seni (tari) pergaulan sosial. Pertunjukan ini dulunya merupakan kelengkapan upacara, ritus kesuburan, baik dalam keluarga (upacara temantèn), pertanian, upacara bersih desa, pesta panen atau tanam padi (Supanggah 2007, 118). Kesenian tayub merupakan kesenian rakyat yang dilakukan oleh beberapa penari putri (disebut juga taledhèk) sambil menyanyi (sindhèn) secara bergantian. Lalu para tamu -biasanya dari kalangan laki-laki- ikut menari dengan para penari. Sembari menari, para tamu memberikan sawer dalam bentuk uang kepada para penari. Gamelan yang digunakan biasanya gamelan yang berlaras slendro. Seiring perkembangan jaman, tayub menggunakan gamelan berlaras lengkap yaitu pelog dan slendro. Adapun repertoar gending yang digunakan meliputi repertoar gending tayub itu sendiri (antara lain Pring Padha 
Pring, Blandhong, Blèndèran, Jamong, OrèkOrèk, Walang Kèkèk, Bribil, Cabawa, Srampat, Warudhoyong, dll), langgam, pop, dangdut, dan sebagainya. Badhutan dan Sragènan juga tidak ketinggalan masuk dalam repertoar tayub (Supanggah 2007, 121). Beragamnya bentuk, jenis, dan jumlah repertoar gending tayub menunjukkan bahwa kesenian rakyat ini semakin diminati oleh kalangan masyarakat yang haus akan hiburan. Gending tayub dapat pula diambil dari repertoar klenèngan yang biasanya digarap ciblon seperti Puspawarna, Sinom Parijatha, Kinanthi Sandhung, dan salah satunya adalah ladrang Mugi Rahayu. Dalam banyak penelitian yang mengangkat mengenai tayub, ladrang Mugi Rahayu sering disebut-sebut sebagai salah satu repertoar gending tayub di daerahnya. Misalnya dalam skripsi karya Supardi dengan judul "Perkembangan Gending Tayub Tulungagungan: 1970-2007" tahun 2008 menyebutkan ladrang Mugi Rahayu sebagai salah satu gending yang disajikan untuk pertunjukan tayub di daerah Tulungagung (Supardi 2008), karya Murlan "Penyajian Garap Musikalitas Gending Tayub Tuban dalam Tradisi Manganan Desa Kumpulrejo" tahun 2012 menyebutkan ladrang Mugi Rahayu sebagai salah satu repertoar gending yang disajikan untuk pertunjukan tayub (Murlan 2013). Ciri-ciri gending tayub adalah sebagai berikut; gending berukuran pendek seperti lancaran, ketawang, dan ladrangan yang bernuansa gembira berlaras slendro. Laras slendro membawa karakter gending menjadi gembira, sigrak, bahkan gecul. Didukung pula dengan garap kendang yang digarap ciblon. Garap gending untuk keperluan tayub hampir sama dengan garap klenèngan, hanya berbeda pada garap kendang yang selalu digarap ciblon untuk menciptakan suasana riang dan gecul. Daerah yang masih menyelenggarakan tayub antara lain: Purwodadi, Pati, Jepara, Sragen, Banyumas, Cepu, Banyuwangi, Tulungagung, Tuban, dll.
Dari pemaparan di atas dapat ditarik satu benang merah bahwasannya Mugi Rahayu hadir dalam dua ranah besar yaitu gending dalam konteks sosial dang ending dalam konteks layanan seni. Konteks sosial mendudukan Mugi Rahayu sebagai gending pahargyan dan panembrama, sedangkan pada konteks layanan seni Mugi Rahayu hadir dalam penyajian klenengan, tari, dan tayub meski tayub dalam koreografinya dapat disebut dengan tari juga. Pada penelitian ini disengaja untuk dipisahkan karena secara prinsip penyajian jelas berbeda antara Mugi Rahayu dalam konteks tari (Beksan Golek Mugi Rahayu) dan Tayub dengan studi kasus di daerah Ngawi.

\section{Jalan Sajian dan Garap Mugi Rahayu}

\section{Pahargyan Penganten}

Setelah mengetahui konteks di mana Mugi Rahayu hadir, maka diskusi diarahkan pada keperbedaan garap dari masing-masing konteks penyajian gending Mugi Rahayu. Perlu ditegaskan, bahwa analisis musikal yang dilakukan tidak mendalam, hal ini dikarenakan karena tidak mungkin menghadirkan notasi seluruh ricikan gamelan Jawa dalam naskah ini dan penekanannya lebih kepada melihat perbedaan-perbedaan yang ada. Untuk itu, pembahasan pertama diawali dari garap Mugi Rahayu sebagai gending pahargyan.

Garap gending Mugi Rahayu dalam kepentingan pahargyan dijabarkan berdasarkan beberapa sumber rekaman dalam bentuk kaset/cakram yang dapat penulis temukan, berikut deskripsi jalannya sajian ladrang Mugi Rahayu:

1. Ladrang Mugirahayu diawali [buka] oleh ricikan rebab, buka gending ini disajikan dalam irama tanggung dan diterima ricikan kendang menggunakan pola kendang kalih ladrang gaya Surakarta.

2. Gending ini pada umumnya 
disajikan dalam irama dadi. Setelah buka terjadi peralihan irama yang ditandai dengan dilambatkannya tempo gending. Gatra ke-satu sampai dengan ke-tiga digarap dengan irama tanggung. Pada gatra ke empat sudah disajikan dalam garap irama dadi. Dalam sajian irama dadi, semua ricikan garap (termasuk garap vokal) memiliki keleluasaan dalam menggarap balungan gending. Garap vokal adalah garap sindhenan dan gerongan. Cakepan atau teks nyanyian yang digunakan adalah bentuk wangsalan, rujakrujakan, dan salisir. Sajian ladrang Mugi Rahayu dapat dilakukan beberapa rambahan durasi disesuaikan dengan peristiwa yang didukungnya.

Jalan sajian di atas merupakan representasi dari garap gending Mugi Rahayu secara umum di mana garap ricikan yang dapat dianalisis sesuai keperluan ini adalah ricikan; kendang meliputi kendang kalih ladranggayaSurakartabaikiramatanggung maupun dadi kemudian kendang ciblon dengan jenis cibon gambyongan, golekan dan pematut. Garap ricikan bonang imbal yang merupakan interaksi dengan garap kendang ciblon dan yang paling dapat ditengarai adalah pada garap vokal yang melibatkan vokal gerong salisir, sindhenan rujak-rujakan, dan sindhenan gawan berupa interaksi antara vokal gerong dan sindhen atau disebut senggakan dan sindhenan gerong. Dalam garap vokal tersebut terdapat teks/cakepan yang dipahami sebagai sindenan gawan gending, teks tersebut yaitu "mugi rahayua-ayem tentrem, mugi rahayua-sayuk rukun" dan "mugi lestaria-ayem tentrem" yang disajikan pada kenong pertama dan kenong kedua, serta isen-isen yang berupa abonabon seperti rama, raden, ya mas, kadangku dewe, dan lain sebagainya. Terdapat pula garap rujak-rujakan yang selalu hadir saat gending digarap ciblon. Hal ini dikarenakan rasa sindhenan rujak-rujakan jumbuh (cocok) saat digarap kendang ciblon yang rasanya prenès. Cakepan/teks yang diungkapkan dalam gending Mugi Rahayu merupakan doa yang ditujukan kepada para pengantin.

\section{Panembrama}

Garap gending Mugi Rahayu diduga memiliki kesamaan dengan garap gending Mugi Rahayu untuk pahargyan penganten. Indikator yang menguatkan gending Mugi Rahayu dipilih sebagai panembrama adalah karena memiliki bentuk gending yang memiliki vokal gerong. Panembrama sering kali memilih gending yang memiliki vokal gerong seperti ketawang Subakastawa, ladrang Sri Widada, dan lain sebagainya. Teks gerong biasanya digubah berdasarkan peristiwa yang akan dihormati dengan gending. Namun, teks untuk gending Mugi Rahayu panembrama tidak ditemukan di perpustakaan Mangkunegaran "Reksa Pustaka" maupun perpustakaan "Radya Pustaka" Surakarta. Garap yang berbeda pada sajian panembrama terletak pada garap vokal. Indikator lain adalah gending berbentuk kecil dan tidak membutuhkan waktu lama dalam penyajiaannya meskipun durasi dapat disesuaikan dengan peristiwa. Selain itu nama Mugi Rahayu dipilih karena memiliki nama yang bermakna mendoakan. Jalannya sajian gending Mugi Rahayu dalam panembrama tidak diketahui secara persis penyajiannya. Namun kemungkinan besar hampir sama dengan garap klenèngan untuk keperluan pahargyan. Perbedaannya, vokal yang dalam sajian pahargyan diwakili oleh sindhen dan gerong, pada konteks panembrama vokal dimasalisasi atau setidaknya lebih dari 2-3 orang (Sumaryono 2013).

\section{Klenengan}

Garap klenengan mandiri memiliki garap tersendiri tanpa dikaitkan dengan kepentingan lainnya, namun tidak menutup kemungkinan garap klenèngan mandiri digunakan untuk mendukung fungsi lain. Klenèngan mandiri bertujuan 
untuk dinikmati dan dihayati sendiri dan/atau sekelompok orang. Pada saat menggarap gending dalam konteks klenèngan, pengrawit memiliki keleluasaan untuk menggarap gending karena tidak dibatasi oleh durasi waktu. Keleluasaan ini membuat pengrawit memiliki kebebasan dalam berkreatifitas. Oleh karena kemampuan, virtuositas, dan kreatifitas pengrawit, maka garap gending Mugi Rahayu menjadi beragam. Faktor lain yang menyebabkan garap gending Mugi Rahayu beragam adalah gaya karawitan dari suatu daerah atau wilayah budaya, diantaranya dalam gaya Surakarta dan gaya Ngawi dan penggunaan gending tersebut untuk berbagai kegunaan atau layanan seni. Ragam garap gending Mugi Rahayu dalam konteks klenengan setidaknya ada tiga versi yaitu instrumental, jangkep dan alus.

\section{Instrumental}

Menurut hemat penulis, sajian instrumental bertujuan untuk menonjolkan garap ricikan- ricikan garap tanpa menggunakan vokal. Sehingga sajian ricikan- ricikan garap secara jelas dapat diidentifikasi cengkok dan wiledannya. Pada sajian secara instrumental, garap gending Mugi Rahayu sama dengan garap klenèngan. Mugi Rahayu yang dimaksud terdapat pada "GendingGending Instrumental: Laler Mengeng" oleh keluarga karawitan RRI (Lokananta Record, ACD 157). Garap ini sama dengan garap klenengan di mana unsur vokal tidak hadri, tetapi secara intsrumentasi contoh rebab - menyajikan pola yang sama dengan garap klenengan.

\section{Jangkep}

Klenèngan jangkep adalah sajian gending yang disajikan dengan seperangkat gamelan yang lengkap. Terdapat ricikan garap seperti rebab, kendang, dan gender. Terdapat juga garap vokal sindhen. Garap dan jalannya sajian klenengan jangkep sama dengan fungsi klenèngan untuk keperluan pahargyan.

\section{Alus}

Ragam garap dipengaruhi karena kreatifitas pengrawit dalam menggarap suatu gending. Misalnya yang dilakukan oleh Suraji ketika menyajikan ladrang Mugi Rahayu sebagai rangkaian gending dari gending besar ke gending yang lebih kecil. Gending Mugi Rahayu secara sengaja digarap secara alus. Garap alus yang dimaksud adalah pengembangan garap dari sejumlah ricikan seperti garap kendang dan garap ricikan balungan. Gending Mugi Rahayu kemudian disebut Mugi Rahayu alus. Berikut jalannya sajian gending Mugi Rahayu alus yang disajikan oleh kelompok Pujangga Laras. Gending Mugi Rahayu merupakan lajengan dari gending Tunjung Karoban laras Slendro pathet Nem yang berbentuk gending kethuk sekawan minggah wolu. Buka diawali dengan menyajikan gending Tunjung Karoban terlebih dahulu kemudian dilanjutkan ke gending Mugi Rahayu yang dijadikan sebagai inggah. Gending digarap dengan pola kendangan kalih wiled. Setelah gending Tunjung Karoban selesai disajikan, kemudian kalajengaken gending Mugi Rahayu. Gending Mugi Rahayu digarap dengan irama dadi, kemudian menjelang kenong ke tiga dengan ater kendang temponya diperlambat untuk peralihan menuju irama wiled. Gending disajikan dalam garap irama wiled selama beberapa kali. Selanjutnya kendang memberikan ater ntuk beralih ke irama dadi dan suwuk dalam irama dadi.

\section{Tari}

Gending - gending dalam karawitan tari sering disebut dengan gending beksan. Karawitan tari hanya berorientasi pada fungsi atau keperluan secara maksimal dengan cara menggunakan, mengurangi, mengembangkan, dan menggarap karawitan untuk kepentingan suatu bentuk penyajian tari. Karawitan tari ini juga 
oleh beberapa kalangan tidak mempunyai arti dan konotasi sebagai pembantu atau dalam arti budak, melainkan membantu dalam memeprtegas, meyangga isi, dan nilai ungkapan estetik. Ladrang Mugi Rahayu digunakan sebagai pendukung dalam sajian tari jenis golek yaitu Golek Mugi Rahayu. Tari Golek berkisah tentang gadis remaja yang sedang bersolek, maka gerakan-gerakan dalam tari golek pun serupa gerakan bersolek seperti miwir rigma (bersisir), tasikan (memakai bedak), atrap cundhuk (memakai cunduk, sejenis hiasan rambut), atrap slepe (memakai sabuk), dolanan supe (memainkan cincin), memakai alis, dan ngilo (berkaca)20. Gerakangerakan tersebut di dalam karawitan tari memiliki kendangan yang sesuai. Oleh karena itu pengrawit tidak dapat menggarap gending sesuai keinginannya sendiri, melainkan disesuaikan dengan gerakan tari. Makna Tari Golek, berdasarkan asal katanya 'golek' dalam bahasa Jawa yang berarti mencari, maka tarian golek memiliki makna pencarian jati diri si gadis remaja tadi. Kaitannya dengan seorang remaja yang sedang mencari jati diri, salah satunya adalah dengan belajar berdandan. Berikut jalannya sajian beksan Golek Mugi Rahayu dalam rangka Lomba Tari Pekan Seni Pelajar Tahun 2012 di Kota Tegal.

Ladrang Mugi Rahayu diawali [buka] dengan ricikan bonang, kemudian diterima ricikan kendang dengan garap pola kendangan kalih ladrang irama tanggung gaya Mataraman sebanyak tiga kali rambahan. Pada rambahan ketiga terjadi peralihan pada kenong keempat menjelang gong dari garap kendang kalih ladrang irama tanggung menuju garap kendangan kalih ladrang irama dadi dengan tempo melambat. Saat gending digarap dengan pola kendangan kalih ladrang merupakan bagian tari yang disebut maju beksan.

Balungan gending digarap dengan balungan baku gending Mugi Rahayu.
Pada saat irama dadi, garap bonang barung menggunakan pola tabuhan pipilan dan gembyangan. Garap gender barung menggunakan pola tabuhan laku sekawan (Purwanto 2020). Garap sindenan menggunakan wangsalan dan gerongan salisir. Kemudian terjadi peralihan dari pola kendangan kalih ladrang irama dadi menuju pola kendangan ciblon pada kenong ke empat menjelang gong. Saat gending digarap ciblon, garap bonang barung menggunakan pola tabuhan imbal dan sekaran, garap gender barung menggunakan pola tabuhan laku wolu, dan garap sindenan menggunakan senggakan, wangsalan, dan gerongan salisir. Pada garap kendang ciblon disebut dengan bagian beksan yang terdiri dari kibar, selingan, dan penghubung. Garap menggunakan kendang ciblon dilakukan sebanyak enam kali rambahan. Pada rambahan ke-enam terjadi peralihan ke kendang kalih ladrang irama dadi. Pada sajian garap kendangan kalih ladrang irama dadi disebut sebagai mundur beksan.

\section{Tayub}

Penyajian karawitan di daerah Ngawi yang diunggah dalam youtube menurut peneliti merupakan "turunan' atau merujuk gaya kesenian Surakarta maupun Yogyakarta atau setidak-tidaknya merujuk pada kedua gaya tersebut. Hal ini dapat diidentifikasikan atas pola dan teknik tabuhan yang sangat mirip dengan pola dan teknik tabuhan kedua gaya dimaksud. Misalnya pola kendangan gaya Mataraman yang digunakan untuk bagian irama tanggung, pola kendangan kalih irama dadi untuk irama dadi, teknik tabuhan kinthilan, dan lain sebagainya.

Garap gending Mugi Rahayu yang peneliti temukan dari satu kasus rekaman dari daerah Ngawi memiliki ragam garap berbeda dengan garap klenèngan pada umumnya. Berikut akan dijelaskan jalannya sajian dan beberapa ricikan garap gending Mugi Rahayu gaya Ngawi yang masih eksis hingga sekarang berdasarkan 
sumber dari Youtube yang diunduh pada tanggal 15 Maret 2016 (diunggah oleh Want83, 25 Oktober 2009).

Gending diawali [buka] oleh ricikan bonang, kemudian diterima ricikan kendang dengan pola kendangan kalih ladrang irama tanggung gaya Mataraman (Sugimin 2019). Irama tanggung digarap sebanyak dua kali rambahan. Saat irama tanggung, ricikan dimainkan dengan volume keras, kecuali ricikan rebab dan gender. Pada rambahan ke dua, peralihan terjadi pada kenong ke tiga yaitu bergantinya pola kendang kalih ladrang irama tanggung menuju pola kendang kalih ladrang irama dadi dengan tempo melambat. Saat irama dadi ricikan digarap dengan volume lirih, yang ditonjolkan adalah garap vokal dan garap rebab. Pada rambahan ketiga, terjadi peralihan dari garap pola kendangan kalih ladrang menuju garap pola kendangan ciblon gambyakan pada kenong ke-empat menjelang gong. Pada rambahan ke empat sudah menggunakan garap kendangan pola gambyakan. Saat disajikan dengan garap kendang ciblon, ricikan balungan menggarap balungan gending dengan cara ditikel. Peralihan dari garap kendang ciblon ke garap kendang kalih ladrang terjadi pada kenong ke empat menjelang gong. Setelah itu garap kendang diulang sampai suwuk.

\section{Kesimpulan}

Eksistensi sbuah gending
dipengaruhi oleh beberapa faktor. Pertama, karena sifat garap karawitan yang lentur dan terbuka. Terbuka dan lentur yang dimaksud adalah adanya kebebasan kreatifitas yang diberikan kepada pengrawit dalam menafsirkan balungan gending yang diwujudkan di dalam permainan ricikan-ricikan ansambel gamelan yang berkualitas. Ke dua, suatu gending yang disajikan dalam fungsi yang beragam akan menjadikan gending tersebut tetap hidu. Karena ia akan disesuaikan dengan keperluan baik sosial maupun hayatan seni/layanan seni. Ke tiga, peran pengrawit sangat penting dalam menentukan garap suatu sajian gending. Hal ini lah yang kemudian menjadikan gending ini menjadi beragam dan memperkuat keberadaan gending dalam khasanah perbendaharaan dan / atau ragam garap gending, sehingga tidak membosankan.

Keberadaan ladrang Mugi Rahayu dapat diidentifikasi melalui frekuensi kehadirannya dalam mendukung keperluan masyarakat Jawa Tengah. Supanggah menegaskan dua fungsi untuk mewadahi keperluan- keperluan tersebut yaitu fungsi sosial dan fungsi hayatan seni. Dalam fungsi sosial ladrang Mugi Rahayu digunakan untuk mendukung acara pahargyan penganten (prosesi sungkeman) dan panembrama untuk menyambut ratu Belanda. Sedangkan fungsi hayatan seni, ladrang Mugi Rahayu digunakan untuk mendukung sajian seni lain seperti beksan dan tayub. Hal ini menunjukkan dan memperkuat keberadaan gending Mugi Rahayuhinggasekarang.Pemilihanladrang Mugi Rahayu untuk memenuhi beberapa fungsi dalam masyarakat didasarkan atas beberapa alasan; (1) nama gending yaitu Mugi Rahayu yang memiliki konotasi positif dan memiliki arti mendoakan "semoga selamat/sentosa/sejahtera", sehingga sesuai untuk acara-acara seperti pahargyan penganten, panembrama), lomba tari, dan festival; (2) bentuk gending yaitu ladrang yang dalam penyajiannya tidak membutuhkan waktu lama. Dua alasan tersebut cukup untuk membuat gending Mugi Rahayu populer dan mendapatkan tempat di hati masyarakat pendukungnya.

\section{Garap ladrang Mugi Rahayu} berbeda dalam memenuhi fungsinya. Dalam sajian klenengan, ladrang Mugi Rahayu memiliki ragam diantaranya garap ladrang Mugi Rahayu ala Ngawi dan garap alus. Ladrang Mugi Rahayu juga digarap dalam sajian untuk mendukung tari/beksan golek yang memiliki nama sesuai dengan nama gendingnya yaitu "Golek Mugi Rahayu". Perbedaan garap ini 
terjadi karena disesuaikan dengan tempat, waktu dan tujuan digelarnya penyajian ladrang Mugi Rahayu akan menjadi selalu up to date atau kontemporer dalam jiwanya yang tetap tradisional. Sifat yang kekinian membuat ladrang Mugi Rahayu akan selalu diterima dan digunakan oleh masyarakat, sehingga karawitan tetap hidup dan berkembang dalam keberagaman.

\section{Kepustakaan}

Hastanto, Sri. 2009. Konsep Pathet. surakarta: ISI Press.

Martopangrawit, R L. 1975. “Pengetahuan Karawitan Jilid I Dan Pengetahuan Karawitan Jilid II." Surakarta: ASKI.

Megawati, Annisa Sari. 2018. “Karawitan Tari Sekar Pudyastuti Karya KRT Sasmintadipura: Struktur Penyajian Dan Garap Kendhangan." Institut Seni Indonesia Yogyakarta.

Murlan, Murlan. 2013. “PENYAJIAN GARAP MUSIKALITAS GENDING TAYUB TUBAN DALAM TRADISI MANGANANDESAKUMPULREJO." Institut Seni Indonesia Surakarta.

Poerwadarminta, W J S. 1939. "Baoesastra Djawa. Groningen, Batavia: B." Wolters uitgevers Maatschappij NV.

Pradja Pangrawit. 1990. Wedapradangga: Serat Sujarah Utawi Riwayating Gamelan. surakarta: STSI Press.

Purwanto, Joko. 2020. “Gender Barung Perspektif Organologi, Teknik, Dan Fungsi Dalam Karawitan Gaya Surakarta." ISI Press.

Subuh, Subuh. 2016. "Garap Gending Sekaten Keraton Yogyakarta." Resital: Jurnal Seni Pertunjukan. https://doi. org/10.24821/resital.v17i3.2227.

Sugimin, Sugimin. 2019. “MENGENAL KARAWITAN GAYA YOGYAKARTA." Keteg: Jurnal Pengetahuan, Pemikiran Dan Kajian
Tentang Bunyi. https://doi. org/10.33153/keteg.v18i2.2398.

Suhartinah, Sudiyono dan. 1981. Riwayat Hidup Dan Pengabdian KRMT Harya Wiryadiningrat: Dalam Biografi Tokoh Karawitan. Yogyakarta: Balai Penelitian Sejarah dan Budaya Yogyakarta.

Sumarsam. 2003. Gamelan: Interaksi Budaya Dan Perkembangan Musikal Di Jawa. Pustaka Pelajar.

Sumaryono, NIDN. 2013. KEPELOPORAN KI WASITODIPURO/KI TJAKRAWASIA DAN KI LARASSUMBOGO DALAM KEHIDUPAN DAN PERKEMBANGAN SENI KARAWITAN DI YOGYAKARTA. Dinas Kebudayaan, DIY.

Supanggah, Rahayu. 2007. "Bothekan Karawitan II." Jakarta: Masyarakat Sèni Pertunjukan Indonesia.

Supardi. 2008. "Perkembangan Gending Tayub Tulungagungan: 1970-2007" Skripsi." ISI Surakarta.

Sutton, R. Anderson. 1986. "The Crystallization of a Marginal Tradition: Music in Banyumas, West Central Java." Yearbook for Traditional Music. https:/ / doi.org/10.2307/768524.

Trustho. 2005. Kendang Dalam Tradisi Tari Jawa. surakarta: STSI Press.

Waridi. 2006. Karawitan Jawa Masa Pemerintahan PB X: Perspektif Historis Dan Teoritis. Surakarta: ISI Press.

Warsapradangga. n.d. "Sesorah Bab Tetabuhan Gamelan."

Widada, Suwadji, Sukardi Mp, E Suwatno Gina, D Sutana, and U Sidik. 2006. "Kamus Bahasa Jawa (Bausastra Jawa)." Yogyakarta: Balai Bahasa Yogyakarta.

Widyastutieningrum, Sri Rochana. 2007. "Tayub Di Blora Jawa Tengah Pertunjukan Ritual Kerakyatan." Surakarta: ISI Press Surakarta. 


\section{Diskografi}

CD 157, Gending-Gending Istrumental. Laler Mengeng, Keluarga Karawitan RRI Stasiun Surakarta Pimp. Turahjo Harjomartono. Surakarta: Lokananta Record.

KGD 263, Pahargyan Vol. 4. Karawitan Raras Riris Irama Pimp. Sardiman. Surakarta: Kusuma Record, 1989.

KGD 130, Pahargyan, Karawitan Raras Riris Irama Pimp. Wakija. Surakarta: Kusuma Record, 1997.

Gending Upacara Temanten Tradisional Yogyakarta. Keluarga Kesenian Jawa RRI Nusantara II Yogyakarta Pimp. Ki Suhardi.. Surakarta: Lokananta Recording.

Gending-Gending Pahargyan Manten. Pimp. N.N. Surakarta: Studio Sembilan Belas STSI Surakarta Yayasan Gendhon Humardani, 2002.

Gerr-Endahe: Orek-Orek Mantingan. Karawitan Roso Cunduk Pimp. Wagiman. Fajar Record, 2005.

\section{Webtografi}

https: / / celoteh4ti.wordpress. com/2012/07/01/tarian-traditionalindonesia-yang-mendunia/\#comments. Dibaca 1 Juli 2016. Pukul 13.30 WIB.

https: / / alangalangkumitir. wordpress.com/2013/11/21/seratsastra-gending-dan-terjemahan/. Dibaca 28 Juli 2016. Pukul 13.34 WIB. http://www.gamelanbvg.com/gendingrangayu. Dibaca 27 April 2016.

Pukul 15.02 WIB.

http://www.youtube.com/.

\section{(Endnotes)}

1 Alit dalam bahasa Jawa berarti kecil. Dalam konteks bentuk gending kata alit berarti bentuk gending kecil berdasarkan jumlah gatra dalam satuan gongnya.

2 Bentuk yang apabila diukur jumlah sabetan dalam satu gatra dan berdasarkan satuan gongnya terdiri dari 32 sabetan dari 8 gatra.

3 Pertunjukan karawitan secara mandiri, dalam artian tidak terikat dengan seni pertunjukan lain, meski dapat hadir pada fungsi layanan seni; eksis dalam acara pernikahan (pahargyan) atau tasyakuran.

4 Secara musikal berarti vokal koor/ kelompok/ bersamaan.

5 Salah satu tari pergauan yang hadir dalam upacara adat dan perayaan bersih desa.

6 Instrumen (alat music bagian dari ensemble besar - gamelan).

7 Buatan/ ciptaan. 